Magdalena Kotulska

Uniwersytet Papieski Jana Pawła II w Krakowie

\title{
Przyczynek do dziejów ołtarza cechu sukienników w kościele farnym w Bieczu
}

Kolegiata pod wezwaniem Bożego Ciała w Bieczu jest jednym z najważniejszych obiektów tego miasta i perłą architektury sakralnej w skali ogólnopolskiej. Zachwyca swą późnogotycką formą i pięknem zróżnicowanego stylistycznie wnętrza, w którym możemy podziwiać ołtarz główny w stylu późnego renesansu flamandzkiego oraz poszczególne kaplice. Fara jest także odzwierciedleniem życia i ważności tego miejsca na przestrzeni dziejów'

Kolegiata w Bieczu nie doczekała się zbyt wielu publikacji naukowych. Brak pełnej monografii kościoła staje się pilnym postulatem badawczym, zwłaszcza że powielane stale informacje ze starszej literatury nie wnoszą nic nowego do tematu, lecz jedynie zaciemniają faktyczny obraz historyczny tego miejsca.

Kościół parafialny jest jednym z centralnych punktów starego miasta, wpisany w ciąg murów obronnych Biecza. Od strony północno-zachodniej przylega doń późnogotycka Baszta Rzeźnicza, pełniąca funkcję dzwonnicy. Obok znajduje się kaplica św. Barbary, niegdyś gotycka, później przebudowana w stylu neogotyckim, a także stara plebania, której część łączy się z dawnymi murami obronnymi miasta. Niektórzy badacze twierdzą, że jest to pozostałość klasztoru Norbertanek z XVI wieku².

1. Epitafia mieszczańskie i pomniki Mikołaja Ligęzy i Piotra Sułowskiego - sędziego grodzkiego bieckiego.

2. Por. J. Suproniuk, Biecz, w: Atlas historyczny Polski. Województwo krakowskie w drugiej połowie XVI wieku, cz. 2, red. S. Trawkowski, M. Wilska, Warszawa 2008, s. 205-215; T. Ślawski, Biecz. Zarys historyczno-krajoznawczy, Biecz 1999, s. 90. 
W historiografii utrwalił się pogląd, że pierwotny, drewniany kościół istniał w tym miejscu już na początku XIV wieku. Nowa murowana fara była wznoszona etapami w ciągu wielu lat. Najstarszą jej częścią jest prezbiterium ukończone przed 1480 rokiem. Budowa korpusu nawowego zakończyła się na początku XVI wieku, a prace nad kaplicami dobiegły końca dopiero w $1560 \mathrm{roku}^{3}$.

Na przestrzeni dziejów wnętrza ulegały stopniowym przeobrażeniom, a to ze względu na zmianę gustu, stylów w sztuce i architekturze, a to prace konserwatorskie. Dzięki temu kolegiata łączy w sobie trzy najbardziej charakterystyczne style: gotyk, renesans i barok. Jednak wnikliwe oko dostrzeże także elementy rokoko i neogotyku ${ }^{4}$.

Późnorenesansowy ołtarz główny jest najcenniejszym elementem wystroju wnętrza. Wykonany został około 1604 roku na podwalinach wcześniejszego późnogotyckiego ołtarza, z którego pochodzą rzeźby figuralne ${ }^{5}$. Jego centralną częścią jest obraz przedstawiający Zdjęcie z krzyża, przypuszczalnie wzorowany na Piecie Michała Anioła ${ }^{6}$.

Badacze spierają się o autorstwo tego dzieła, niewątpliwie unikatowego w tej części Europy. Obraz Opłakiwanie Chrystusa, bo tak również jest określany w literaturze fachowej, najprawdopodobniej wypłynął z warsztatu włoskiego renesansu, dzieło bowiem ma cechy stylu Tycjana i Corregia. Istnieja dwa niemalże identyczne przedstawienia, pierwszy autorstwa Wawrzyńca Sabbatiniego znajdujący się w zakrystii bazyliki św. Piotra w Watykanie, drugi, Antonio Vivianiego, przechowywany w kościele s. Maria ai Monti w Rzymie. W archiwum parafialnym nie znaleziono dotychczas żadnych wzmianek na temat tego, kto mógłby być autorem tego obrazu ani jakim sposobem trafił on do Biecza ${ }^{7}$.

Prezbiterium pokryte jest polichromią autorstwa Włodzimierza Tetmajera, wspomaganego przez artystów bieckich: Apolinarego Kotowicza i Józefa Wrzesińskiego. Dzieło prezentuje poczet władców polskich od ks. Kingi

3. Por. W. Fusek, Biecz $i$ dawna ziemia biecka na tle swych legend, bajek, przesadów i zwyczajów, Biecz 1998, s. 55.

4. $\quad$ Por. T. Ślawski, Biecz. Zarys historyczno-krajoznawczy, dz. cyt., s. 90-91.

5. $\quad$ Ołtarz z 1605 roku zob. Biecz $w$ dawnej grafice $i$ fotografii, Biecz 2004, s. 8.

6. Por. T. Ślawski, Biecz. Zarys historyczno-krajoznawczy, dz. cyt., s. 99-104.

7. Por. A. Bochnak, Obraz włoski z XVI wieku w kościele parafialnym w Bieczu, w: Biecz: studia historyczne, pod red. R. Kalety, przy współpr. F. Błońskiego, Wrocław 1963, s. 275-279. 
do Zygmunta III Wazy. Nawę główną z prezbiterium łączy belka tęczowa z 1488 roku z umieszczoną na niej sceną Pasji ${ }^{8}$.

Nad głównym wejściem znajduje się drewniany chór muzyczny z wielkimi organami z końca XIX wieku, poniżej po prawej i lewej stronie umieszczono stalle, a w ścianach epitafia mieszczańskie. Do obu naw bocznych przylegają rzędy kaplic, z każdej strony po cztery, fundowanych przez poszczególne cechy rzemieślnicze, działające niegdyś na terenie Biecza. Dobrze rozwinięte rzemiosło reprezentowane było przez około 30 różnych profesji, z których sukiennictwo i płóciennictwo wiodło tutaj prym.

Po północnej stronie kościoła, pierwsza od zachodu kaplica, zwana Kromerowską ${ }^{9}$, ufundowana została przez bp. Marcina Kromera, pierwotnie posiadała ołtarz pod wezwaniem Rozesłania Apostołów, niestety niezachowany do naszych czasów ${ }^{10}$. Druga z kolei kaplica przypisywana jest cechowi szewców. Obecnie centralnym jej punktem jest ołtarz rokokowy z XVIII wieku z rzeźbami św. Kazimierza i św. Jana Nepomucena. Trzecia z kolei kaplica uznawana jest za dawną kaplicę stolarzy, snycerzy i rymarzy. Stoi w niej ołtarz Matki Bożej Gromnicznej z 1633 roku z rzeźbami przedstawiającymi Niepokalane Poczęcie NMP w otoczeniu aniołów ${ }^{11}$.

Ostatnia w tym ciągu kaplica św. Katarzyny i św. Michała, przedmiot naszych rozważań, była dawniej w posiadaniu cechu tkaczy ${ }^{12}$. Obecnie znajduje się w niej ołtarz rokokowy z drugiej połowy XVIII wieku ufundowany przez rajcę Michała Bochniewicza około 1750 roku. Z kaplicy tej można przejść do oratorium Królowej Jadwigi (tzw. kaplica „Na Przemienieniu Pańskim" $)^{13}$.

8. Por. B. Duda, A. Piotrowska, Szlak Świętej Jadwigi Królowej w Bieczu, Biecz 2006, s. 42-43; J. A. Nowobilski, Fara w Bieczu: sakralne malarstwo ścienne Włodzimierza Tetmajera, Kraków 1994, s. 59-69.

9. Zwana także kaplicą Chrystusa Ukrzyżowanego lub krawców.

10. Lub/i Chrystusa Ukrzyżowanego (1616), który przeniesiono do ołtarza głównego, por. W. Fusek, Biecz i dawna ziemia biecka..., dz. cyt., s. 56, 58.

11. Por. S. Tomkowicz, Powiat gorlicki, w: Teka Grona Konserwatorów Galicyi Zachodniej, t. 1, Kraków 1900, s. 175-230; T. Ślawski, Biecz. Zarys historyczno-krajoznawczy, dz. cyt., s. 95-96; Mała Poligrafia Redemptorystów, Kolegiata Bożego Ciała w Bieczu, Tuchów 2003, s. 9.

12. Inaczej zwana kaplicą pw. św. Michała i św. Katarzyny lub kupców.

13. Por. T. Ślawski, Biecz. Zarys historyczno-krajoznawczy, dz. cyt., s. 96; Mała Poligrafia Redemptorystów, Kolegiata Bożego Ciała w Bieczu, dz. cyt., s. 9-10; W. Fusek, Biecz i dawna ziemia biecka..., dz. cyt., s. 55, 58. 
W rzędzie kaplic od strony południowej znajdują się następne cztery przypisywane możnym rodzinom szlacheckim i mieszczanom. Pierwsza od wschodu z obrazem św. Józefa i Chrystusa Miłosiernego, ufundowana została przez cech kowali. Druga kaplica należała niegdyś do cechu rzeźników z ołtarzem św. Tekli z XVIII wieku. Trzecia, pw. św. Jana Kantego, zwana też Sułowskich, dawniej pozostająca pod opieką cechu piekarzy. Ostatnia kaplica z obrazem Ecce Homo z XVIII wieku należała niegdyś do Wielopolskich i Ligęzów ${ }^{14}$.

Wyposażenie kościoła farnego w Bieczu świadczy o obecności wielu znamienitych artystów z kraju i z zagranicy, a jego zabytkowe wyposażenie jest jednym z piękniejszych w Polsce. Poza wyjątkowymi kaplicami i ołtarzem głównym warto wymienić także stalle z XV wieku i pulpit muzyczny, wykonane z niebywałą precyzją i artystycznym kunsztem przez bieckich rzemieślników-stolarzy. Spośród wyjątkowych zabytków wnętrza bieckiej fary należy uwzględnić także spiżową chrzcielnicę z 1459 roku czy wczesnobarokową skrzynię, połączoną z pulpitem na kancjonały pochodzącą z 1633 roku. Kolegiata biecka skrywa jeszcze wiele innych cennych obiektów sztuki sakralnej, jednak nie one są głównym tematem tego artykułu ${ }^{15}$.

Bardzo skromne są informacje o pierwszych pracach konserwatorskich przeprowadzonych w kolegiacie w Bieczu. Niewątpliwie wojny, kataklizmy czy epidemie miały negatywny wpływ na zachowanie budowli oraz jej wyposażenie. Na funkcjonowaniu kościoła i wspieraniu go przez okoliczną ludność niekorzystnie odbijały się następnie zmiany w Kościele - reformacja czy upadek zasad moralnych kleru. Poważniejsze prace zabezpieczające wyposażenie wnętrza kościoła wykonano na przełomie XVI i XVII wieku, w konsekwencji jego opłakanego stanu. Można przypuszczać, że właśnie wtedy mógł ulec zniszczeniu pierwszy ołtarz tkaczy, którym tutaj będziemy się zajmowaćit ${ }^{16}$ Zachowała się urzędowa relacja rajców bieckich z 1558 roku, w której czytamy, że kościół farny był zdezolowany, dach i krokwie nad zakrystią zbutwiałe, sklepienie również poniszczone ${ }^{17}$. W akcie komisarskim

14. Por. T. Ślawski, Biecz. Zarys historyczno-krajoznawczy, dz. cyt., s. 107-111; Mała Poligrafia Redemptorystów, Kolegiata Bożego Ciała w Bieczu, dz. cyt., s. 23-25.

15. M. Rehorowski, Zabytkowe sprzęty kościoła parafialnego w Bieczu, w: Biecz: studia historyczne, dz. cyt., s. 288-309.

16. Por. T. Ślawski, O renowacji i konserwacji zabytków w Bieczu, Biecz 2006, s. 39.

17. Archiwum Narodowe w Krakowie Oddział I na Wawelu [dalej: ANK], Akta miasta Biecza, sygn. 29/101/0.2/6 (Dep 8), s. 537-538. 
z 21 czerwca 1568 roku czytamy: [...] „a iżesmy z oglądania poprawy miasta wyrozumieli, iż tej poprawy wielka potrzeba, bo parkany murowane, na niektórych miejscach poprawy i pobicia takież i kościół dachu, wieże brony potrzebują; takież i około dział, hakownic, ołowu, prochów wielkie zaniedbanie do tego czasu [się] działo, przetożmy to zarazem reformować tak znowu jako też i oprawić rozkazali za takowąż instygację cechmistrzów imieniem pospolitego człowieka $[\ldots]^{118}$.

W aktach procesu między miastem Bieczem a proboszczem bieckim z 1659 roku czytamy, że: „[...] Ciosy potężne kamienne z okien zakrystii, sumptibus magnis per antecessores wmurowane, sine scitu także provisorum wyłomać kazał, a ceglane cum periculo eiusdem ecclesiae powprawiać sumptibus ecclesiae minime parcendo, lubo dosyć in proventibus ubogi kościół [...]"19.

"Tygodnik Ilustrowany" z 1859 roku odnotował, że Biecz popadał w coraz większą ruinę i zapomnienie. Miasto, które niegdyś było nazywane „małym Krakowem”, traciło najcenniejsze zabytki sztuki świeckiej i sakralnej ze względu na brak konserwacji tychże obiektów czy zabezpieczenia ich przed niszczeniem. Ciekawe jest też to, że autor wymienił jedynie sześć kaplic w farze, a nie osiem. Być może jest to zwyczajna pomyłka ${ }^{20}$.

Kolejne lata obfitowały w mniejsze lub większe fundacje, renowacje i naprawy. Zorganizowanie największej akcji remontowej kościoła parafialnego w Bieczu przypisuje się ks. Tomaszowi Jaszczórowi, który objął probostwo w 1859 roku, i Karolowi Rogawskiemu, ziemianinowi z niedalekich Ołpin. Były to głównie prace zabezpieczające budowlę przed zawaleniem. W 1883 roku powołano Komitet

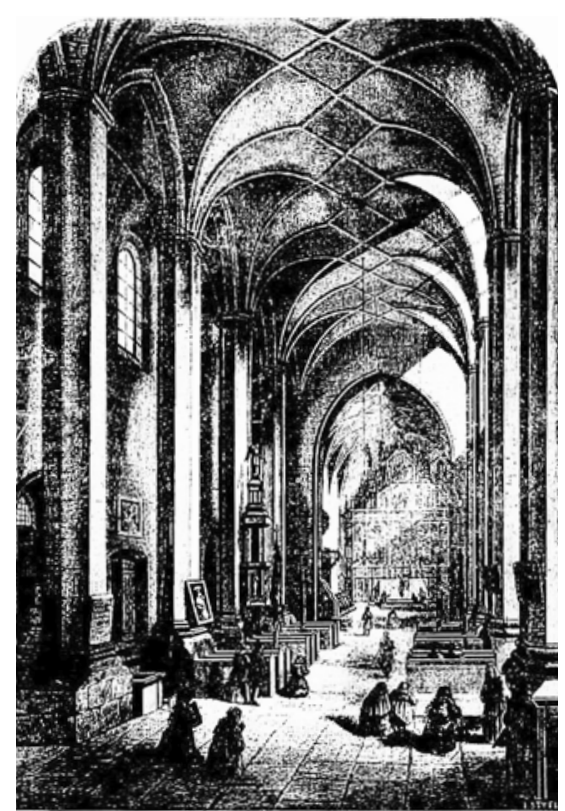

Wnętrze fary w Bieczu wg "Tygodnik Ilustrowany" $1859 \mathrm{nr} 10$, s. 76

18. F. Bujak, Materiały do historii miasta Biecza (1361-1632), Kraków 1914, s. 102-107.

19. ANK, Akta miasta Biecza, sygn. 29/101/0/5/35 (Dep 33), s. 9.

20. Wnętrze fary w Bieczu, "Tygodnik Ilustrowany" $1859 \mathrm{nr}$ 10, s. $75-76$. 
Restauracji Zabytków Pomnikowych Miasta Biecza, który miał nadzorować dalsze prace konserwatorskie ${ }^{21}$.

Po czasach zawieruchy II wojny światowej prace zabezpieczające ten wspaniały obiekt sakralny były prowadzone systematycznie, w zależności od potrzeb i funduszy. Pieczę nad kolegiatą Bożego Ciała w Bieczu objęła Kuria Metropolitalna w Krakowie, Muzeum w Bieczu, Pracownia Konserwacji Zabytków w Krakowie, a także grono prywatnych darczyńców, którym dobro tej świątyni leży na sercu.

Mając zatem świadomość olbrzymiej wartości zabytków sztuki sakralnej znajdujących się we wnętrzu kolegiaty bieckiej, które w bardzo skrótowej formie opisano powyżej, spróbujmy zastanowić się nad udziałem mieszkańców w funkcjonowaniu parafii na przełomie XVI i XVII wieku. Fundatorami i dobroczyńcami kościoła przeważnie byli możni rajcy miejscy, którzy finansowali różne przedsięwzięcia w kościele. Fundowali prywatne kaplice, ofiarowywali drogocenne paramenty, zamawiali obrazy i rzeźby u wybitnych artystów. Podobnie funkcjonowały cechy miejskie, które w swoich statutach miały zapisy odnoszące się do fundacji kaplic cechowych czy opłat dla altarystów zobligowanych do opiekowania się kaplicami.

Bibliografia odnosząca się do dziejów Kolegiaty Bożego Ciała w Bieczu, jak wspomnieliśmy, jest dość skromna. Badania materiału archiwalnego, głównie wizytacji biskupich oraz ksiąg miejskich, w połączeniu z informacjami zaczerpniętymi z literatury przedmiotu pozwalają na wyjaśnienie historii jednej ze wspomnianych fundacji, ołtarza i kaplicy cechu sukienników.

W Archiwum Narodowym na Wawelu przechowywany jest dokument fundacyjny ołtarza cechu sukienników pod wezwaniem Bożego Ciała w kościele parafialnym w Bieczu. Akt pochodzi zapewne z 1483 roku, choć nie nosi daty wystawienia, i jest pierwszym zachowanym do naszych czasów zapisem odnoszącym się do tego ołtarza.

Dokument ten spisany na polecenie mistrzów cechu sukienników bieckich adresowany był do biskupa krakowskiego kard. Fryderyka. Wystawcy potwierdzali w nim fundację ołtarza pod wezwaniem Bożego Ciała usytuowanego w prezbiterium kościoła parafialnego w Bieczu. Prosili biskupa o jego oficjalną erekcję i zatwierdzenie. Wieczyste prawo patronatu miało należeć

21. Por. T. Ślawski, O renowacji i konserwacji zabytków w Bieczu, dz. cyt., s. 58-66. 
do cechu, a opiekować się miał nim wyznaczony przez braci cechowych duchowny. W razie konfliktu przy wyborze altarysty rozjemcami w sprawie mieli być rajcy bieccy. Dokument pierwotnie był opatrzony pieczęcią cechu, z której pozostał tylko fragment taśmy pergaminowej ${ }^{22}$.

Zgodnie z zapisem ołtarz był uposażony czynszem w wysokości dziesięciu grzywien, z biskupów krakowskich, w których odnotowywano, dość skrupulatnie, wyposażenie i stan techniczny kościołów, a przez to ukazywano istotne przemiany, jakie na przestrzeni dziejów zachodziły w poszczególnych świątyniach. Poza charakterystyką samych budynków kościelnych czy elementów wyposażenia liturgicznego istotną ich częścią były opisy kaplic i ołtarzy z dokładnymi danymi na temat ich fundacji, obowiązków altarystów i ogólnego wyglądu danej świątyni.

Najstarsza zachowana wizytacja parafii w Bieczu pochodzi z 1565 roku i była wykonana na polecenie bp. Filipa Padniewskiego. Czytamy w niej, że kościół parafialny pod wezwaniem św. Piotra i Pawła spełniał wszystkie wymagane kryteria, tzn. miał odpowiednio ogrodzony cmentarz, zamkniętą i czystą chrzcielnicę, ponadto wszelkie paramenty liturgiczne i księgi kościelne były na wyposażeniu parafii. Czytamy dalej, że proboszczem był Wojciech Pruszkowski, a jego zastępcą Stanisław Krodner. Dodatkowo w parafii pracowało trzech wikariuszy i trzech altarystów. Jednym z nich był Szymon Detrich z Biecza, wypędzony z plebanii w Rozembarku. Niestety autor nie podaje szczegółowych informacji, nie możemy zatem stwierdzić, jaką kaplicą mógł się opiekować. Personalia pozostałych dwóch altarystów są nieznane ${ }^{23}$.

Następną w kolejności wizytacją była wykonana na polecenie kard. Jerzego Radziwiłła 20 września 1597 roku, za probostwa Piotra Piotrowskiego. Wizytacje Radziwiłła były to szczegółowe protokoły z jego nierzadko osobistych wizyt w parafiach dekanatu krakowskiego, bieckiego i lelowskiego. Akt dotyczący parafii w Bieczu został spisany na blisko ośmiu kartach pergaminowych. W porównaniu z innymi wizytacjami ta wydaje się być wyjątkowo długa i sumienna ${ }^{24}$.

Kościół osobiście odwiedzili prepozyt tarnowski Krzysztof Kazimierski, oficjał pilznieński i notariusz publiczny Stanisław, syn Jana Zięby

22. Zob. ANK, Cechy rzemieślnicze miasta Biecza, zespół 29/122, sygn. 29/122/0/4/4 (dawna Dok Dep 001).

23. Zob. AKMKr, wizytacje biskupów krakowskich (1565-1570), sygn. AV Cap 1, s. $153-154$.

24. Zob. AKMKr, wizytacje biskupów krakowskich (1597), sygn. AV Cap 9. 
z Szynwałdu. Na żądanie wizytatora rajcy miejscy przedstawili dokumenty fundacyjne wszystkich kaplic w farze, wśród nich ołtarz pod wezwaniem Bożego Ciała przypisywany sukiennikom wymieniony został jako dziesiąty z kolei. W zapisie ujęto obowiązki altarzysty: jego zadaniem było trzy razy w ciągu tygodnia odprawienie mszy do krzyża Chrystusa, za grzechy tkaczy oraz za zmarłych członków cechu.

Kolejna wizytacja Radziwiłła miała miejsce krótko po tej pierwszej, 18 lutego 1598 roku. Wówczas biskup na nowo zorganizował pracę wikariuszy przy farze bieckiej. Przy okazji wymieniono uposażenie wszystkich ołtarzy, potwierdzając 10 grzywien czynszu na ołtarz pod wezwaniem Bożego Ciała ${ }^{25}$.

Kolejna wizytacja została przeprowadzona w 1602 roku z polecenia bp. Bernarda Maciejowskiego przez prepozyta i dziekana wojnickiego Andrzeja Chrościńskiego. Prepozytem kościoła parafialnego był wówczas notariusz biskupi Marcin Kłoczyński, kaznodzieją - Piotr Zielonacki z Chodziesza w diecezji poznańskiej. Przy kościele było sześciu wikariuszy, dwóch gracjalistów, organista i dwóch dzwonników. Zatem obsada duchownych systematycznie się powiększała. Z protokołów dowiadujemy się, że fara posiadała 15 ołtarzy, a każda kaplica miała swoje paramenta: ampułki, antepedia, kielichy, stroje. Interesujący nas ołtarz sukienników wymieniony został jako drugi, z przynależącymi do niego paramentami liturgicznymi i krzyżem "[...] crux argentia appendum marita [...]"26. Zanotowano także, że cech tkaczy posiada obraz Matki Bożej nawiedzającej św. Elżbietę ${ }^{27}$.

Wizytacja z 1608 roku odbyta przez prepozyta bieckiego Marcina Kłocińskiego nie wnosi nic nowego do badanego przez nas tematu ${ }^{28}$.

Dopiero kolejna z 1618 roku przeprowadzona przez archidiakona sądeckiego Mikołaja Wąssowicza przynosi przełom w omawianym tu zagadnieniu. Do tej bowiem pory w wizytacjach podawano, że cech sukienników posiada ołtarz pod wezwaniem Bożego Ciała. W tej wizytacji po raz pierwszy pojawiła się informacja, jakoby tkacze posiadali własną kaplicę, w której znajdował się ołtarz pod wezwaniem św. Wawrzyńca "[...] Apparamenta capellae fraternitas

25. Zob. AKMKr, wizytacje biskupów krakowskich (1598), sygn. AV Cap 65, s. 37-38; F. Bujak, Materiały..., s. 144-146.

26. AKMKr, wizytacje biskupów krakowskich (1602), sygn. AV Cap 21, s. 96.

27. Zob. AKMKr, wizytacje biskupów krakowskich (1602), sygn. AV Cap 21, s. 95-110.

28. Zob. AKMKr, wizytacje biskupów krakowskich (1608), sygn. AV Cap 26, s. 437. 
textorum [...] ad altare consecrato tituli sancti Laurenty [...]"29. Nie odnotowano żadnej wzmianki o wezwaniu Bożego Ciała ${ }^{30}$.

Kolejna wizytacja z tego samego roku potwierdza istnienie w kaplicy cechu tkaczy ołtarza św. Wawrzyńca, którym zajmował się Szymon Opatowicz. Nie zachowały się jednak żadne, chociażby szczątkowe informacje, które mogłyby wskazywać na dalsze losy tego ołtarza. Wątpliwe wydaje się także, aby nowe wezwanie św. Wawrzyńca było związane z jakimś mistrzem cechowym czy szczególnym dobrodziejem tejże kaplicy. Być może dalsza kwerenda rzuci nowe światło na ten aspekt sprawy ${ }^{31}$. Najbardziej prawdopodobne wydaje się, że pierwszy ołtarz sukienników uległ zniszczeniu, a cech postanowił ufundować nowy, w nowo wybudowanej kaplicy cechowej.

W trakcie wizytacji kanoniczej z 1767 roku odnotowano kaplicę płócienników i tkaczy, jednak o już zupełnie innym wyposażeniu. Być może jeszcze w drugiej połowie XVIII wieku cech funkcjonował, jednak bardziej prawdopodobne wydaje się to, że wówczas już używano tej nazwy zwyczajowo, na określenie kaplicy, która kiedyś należała do sukienników. Wedle protokołu wizytacji w kaplicy znajdował się obraz Matki Boskiej Tuchowskiej, krucyfiks drewniany i dwie Pasje, w tym jedna nowa. Na postumencie Matka Najświętsza, św. Jan i trupia główka oraz Agnus Dei. Obok św. Jan ze znakami ewangelistów. Na zasuwie obraz św. Joachima i św. Anny z Najświętszą Panną ${ }^{32}$. W dokumentach z tej samej wizytacji wymieniany jest ołtarz św. Michała Archanioła. Jest to o tyle istotne, że w późniejszych źródłach i publikacjach pojawia się informacja o umieszczeniu w ołtarzu głównym kaplicy tkaczy obrazu św. Michała depczącego Szatana, który to obraz znajduje się tam do dnia dzisiejszego. Podobnie jak obraz Matki Boskiej Tuchowskiej umieszczony w górnej części ołtarza, który nieprzerwanie należy do tej kaplicy od XVIII wieku.

W księgach miejskich Biecza oraz statutach cechowych odnaleźć można zapisy dotyczące obowiązków rzemieślników względem fundacji w kościele. Poza ogólnikowymi wzmiankami o zatwierdzonych przez cech opłatach, zapalaniu i gaszeniu świec w kościele czy uczestnictwie w pogrzebach członków

29. AKMKr, wizytacje biskupów krakowskich (1618), sygn. AV Cap 37, s. 29.

30. Zob. AKMKr, wizytacje biskupów krakowskich (1618), sygn. AV Cap 37, s. 24-34.

31. Zob. AKMKr, wizytacja biskupów krakowskich (1618), sygn. AV Cap 39, s. 253.

32. Zob. AKMKr, wizytacje biskupów krakowskich (1767), sygn. AV 49, s. 235. 
cechu, dokumenty te nie wnoszą jednak nic nowego do interesującej nas kwestii zmian lokalizacji i wezwania ołtarza ${ }^{33}$.

Bez wątpienia pierwotny ołtarz cechu tkaczy pod wezwaniem Bożego Ciała był umieszczony w prezbiterium, być może w miejscu, gdzie obecnie ustawione są stalle. Jeszcze na początku XVII wieku w nowej kaplicy tkaczy ufundowano ołtarz z wizerunkiem św. Wawrzyńca. Ten nie zachował się do naszych czasów. Gdy zaś pod koniec XVIII wieku cech zaczął zanikać, również kaplica straciła swoich dawnych patronów. Wówczas zapewne umieszczono w niej późnobarokowy obraz św. Michała depczącego Szatana ${ }^{34}$.

Witold Fusek, mieszkaniec XIX-wiecznego Biecza, magister farmacji z zawodu, a badacz historii tego miasta z zamiłowania, poświecił kilka uwag zabytkom, w tym również farze bieckiej. Wprawdzie przygotowana przez niego publikacja jest dziełem amatora, niemniej cenne są zawarte w niej uwagi naocznego świadka, a także fakt wykorzystania źródeł, które nie dotrwały do naszych czasów ${ }^{35}$. Nas szczególnie interesuje podany przez niego wykaz ołtarzy z ich fundatorami i datą powstania ${ }^{36}$.

1. Zwiastowania 1415 (Agnieszka Tyczowa)

2. Św. Katarzyny 1469 (rajcy miejscy)

3. Św. Barbary 1473 (Szczepan Szpiek)

4. Przemienienia 1481 (Mikołaj Ćwikła)

5. Bożego Ciała 1483 (cech sukienników)

6. Św. Stanisława 1485 (Tomasz Siołowski)

7. Matki Bożej Śnieżnej (ad Nives) 1496 (Jan Karwacjan Gorlicki - 300 fl.)

8. Św. Anny 1511 (ks. Jan z Tyczyna)

9. Rozesłania Apostołów - erygowany w 1520 przez bp Jana Konarskiego (Stanisław Mądry)

10. Św. Mikołaja 1598 (Mikołaj Ligęza; umieszczony w zakrystii)

11. Wielki MB i św. Piotra 1604 (?)

12. Chrystusa Ukrzyżowanego 1616 (kaplica krawców?)

33. Zob. ANK, Akta miasta Biecza, sygn. 29/101/0/3/24 (dawna Dep 3) s. 50-53; F. Bujak, Materiały..., s. 123-125, 228-229

34. Obraz ten został w latach 1999-2005 poddany konserwacji dzięki środkom otrzymanym od Wojewódzkiego Konserwatora Zabytków w Krakowie, por. T. Ślawski, O renowacji i konserwacji zabytków w Bieczu, dz. cyt., s. 153, 159.

35. Zob. W. Fusek, Biecz i dawna ziemia biecka..., dz. cyt., passim.

36. Prawdopodobnie chodzi o inwentarz fary w Bieczu spisany przez ks. Kajetana Piekosińskiego w latach 1769-1772 i księgę odpisów dokumentów i inwentarza kościoła farnego w Bieczu. 
13. MB Gromnicznej 1633 (cech wielki?)

14. Św. Jana Kantego 1670 (kaplica Sułowskich?)

15. Św. Antoniego 1700 (I. Bałda)

16. Św. Michała 1750 (M. Bochniewicz)

17. Św. Tekli 1750 (S. Wiktor)

18. Pana Jezusa Miłosiernego 1870 (J. Gromnicki)

19. Św. Józefa (?)

Innym źródłem wykorzystanym przez Fuska jest spis z 1872 roku 10 ołtarzy z datą ich powstania. Ołtarz św. Michała Archanioła ufundowany miał być w 1750 roku. Biorąc pod uwagę fakt, że według wizytacji z 1768 roku ołtarz pod tym wezwaniem znajdował się już w kaplicy sukienników, przytoczona data fundacji wydaje się wiarygodna ${ }^{37}$.

Najprawdopodobniej nie zachowały się żadne informacje o tym, co stało się z pierwotnym ołtarzem tkaczy. Zapewne niszczał, aż w końcu uległ całkowitemu rozpadowi. Wielce prawdopodobne jest, że ołtarz tkaczy pod wezwaniem Bożego Ciała został utracony bezpowrotnie.

Oddając do rąk czytelników ten przyczynek do dziejów ołtarza i kaplicy cechu sukienników w Bieczu, mamy świadomość, że zagadnienie to wymaga jeszcze dalszej kwerendy źródłowej, która być może rozjaśni zasygnalizowane tutaj wątpliwości.

37. Por. W. Fusek, Biecz i dawna ziemia biecka..., dz. cyt., s. 55-67. 


\section{Bibliografia}

Źródła rękopiśmienne

\section{Archiwum Narodowe w Krakowie Oddział I na Wawelu}

Cechy rzemieślnicze miasta Biecza, zespół 29/122, sygn. 29/122/0/4/4

(dawna Dok Dep 001)

Cechy rzemieślnicze miasta Biecza, zespół 29/122, sygn. 29/101/0/2/5

(dawna Dok Dep 007)

Akta miasta Biecza, sygn. 29/101/0/3/24 (dawna Dep 3)

Akta miasta Biecza, sygn. 29/101/0/5/35 (Dep 33)

Archiwum Kurii Metropolitalnej w Krakowie

AV Cap 1

AV Cap 9

AV Cap 21

AV Cap 26

AV Cap 37

AV Cap 39

AV Cap 65

AV 49

Actorum Offic. Cracoviensis, vol. 18, 20, 37

\section{Opracowania}

Biecz: studia historyczne, pod red. R. Kalety, przy współpr. F. Błońskiego, Wrocław 1963.

Bujak F., Materiały do historii miasta Biecza (1361-1632), Kraków 1914.

Duda B., Piotrowska A., Szlak Świętej Jadwigi Królowej w Bieczu, Biecz 2006.

Fusek W., Biecz i dawna ziemia biecka na tle swych legend, bajek, przesąów i zwyczajów, Biecz 1998.

Mała Poligrafia Redemptorystów, Kolegiata Bożego Ciała w Bieczu, Tuchów 2003. 
Nowobilski J. A., Fara w Bieczu: sakralne malarstwo ścienne Włodzimierza Tetmajera, Kraków 1994.

Rybarski R., Gospodarka miasta Biecza w XVI i poczatkach XVII stulecia, Biecz 1998.

Suproniuk J., Biecz, w: Atlas historyczny Polski. Województwo krakowskie w drugiej połowie XVI wieku, cz. 2, red. S. Trawkowski, M. Wilska, Warszawa 2008 s. 205-215.

Ślawski T., Biecz. Zarys historyczno-krajoznawczy, Biecz 1999.

Ślawski T., Biecz. Album, Biecz 2001.

Ślawski T., O renowacji i konserwacji zabytków w Bieczu, Biecz 2006.

Tomkowicz S., Powiat gorlicki, w: Teka Grona Konserwatorów Galicyi

Zachodniej, t. 1, Kraków 1900, s. 167-319.

Wnętrze fary w Bieczu, "Tygodnik Ilustrowany" 1859 nr 10, s. 75-76. 


\section{Abstrakt}

Magdalena Kotulska

Przyczynek do dziejów ołtarza

cechu sukienników w kościele farnym w Bieczu

\author{
Słowa kluczowe: \\ Włodzimierz \\ Tetmajer, Marcin \\ Kromer, Kolegiata \\ pod wezwaniem \\ Bożego Ciała \\ w Bieczu, cech \\ sukienników, \\ dokument \\ fundacyjny ołtarza \\ cechowego
}

Artykuł prezentuje krótki zarys historii kolegiaty pod wezwaniem Bożego Ciała w Bieczu, która stanowi jedynie wprowadzenie do omówienia głównego tematu tekstu, czyli historii ołtarza i kaplicy cechu sukienników bieckich. Obecnie przyjmuje się, że kaplica pod wezwaniem św. Katarzyny i św. Michała znajdowała się niegdyś w posiadaniu tego cechu. W najstarszych źródłach dotyczących badanego tematu pojawia się jednak wzmianka o pierwotnym ołtarzu cechowym, pod wezwaniem Bożego Ciała. Niespójność ta wynika najprawdopodobniej z istnienia dwóch fundacji cechowych, na początku samego ołtarza pod wezwaniem Bożego Ciała, a z czasem całej kaplicy. Należy również zaznaczyć, że znajdowały się one w dwóch różnych miejscach we wnętrzu fary bieckiej. Autorka nie natrafiła na jakiekolwiek wzmianki, które świadczyłyby o tym, że pierwszy ołtarz sukienników mógł przetrwać do obecnych czasów. Tekst został wzbogacony o edycję źródłową: Starsi cechu sukienniczego miasta Biecza zawiadamiaja kardynała Fryderyka o ufundowaniu i uposażeniu ołtarza pw. Bożego Ciała w kościele parafialnym w Bieczu z 1483 roku. Dokument ten jest przechowywany w zbiorach Archiwum Narodowego w Krakowie. 


\section{Abstract}

Magdalena Kotulska

A Contribution to the History of the Altar of the Clothiers' Guild in the Parish Church in Biecz

The article presents a short outline of the history of the Corpus Christi Collegiate Church in Biecz, which constitutes only an introduction to a wider discussion of the main subject of the text, i.e. the history of the altar and the chapel of the Biecz clothiers' guild. It is currently held that St. Catherine's and St. Michael's chapel was owned by the guild. However, the earliest sources concerning the investigated subject contain a mention of the original Corpus Christi altar founded by the guild. This inconsistency is presumably caused by the co-existence of two guild foundations, initially the Corpus Christi altar, and later the entire chapel. It should also be emphasized that they were located in two different places inside the Biecz parish church. The author did not find any evidence which would suggest that the first altar could survive until today. The article has been enhanced by a source edition: The elders of the clothiers' guild of the town of Biecz notify Cardinal Frederic of the foundation and provision of the Corpus Christi alter in the Biecz parish church of 1483. The document is stored in the National Archive in Krakow.
Keywords: Włodzimierz Tetmajer, Marcin Kromer, Corpus Christi Collegiate Church in Biecz, clothiers' guild, foundation document for the guild altar 